\title{
POLYADENOPATHY - A MULTIDISCIPLINARY APPROACH
}

\author{
Alexandra Jichitu ${ }^{1}$ Laura Maria Manea ${ }^{1}$, Vlad Pînzariư ${ }^{1}$, Nicoleta Mihaela Sprîncenatu ${ }^{1}$ \\ Irina Iuliana Hanu ${ }^{1}$, Raluca Mihaela Popescu ${ }^{1}$, Claudia Mihaela Chirilă ${ }^{1}$, \\ Mihnea George Orghidan², Valentin Caius Coșei \\ ${ }^{1}$ Colțea Clinical Hospital, Bucharest, Romania \\ 2"Marius Nasta", Pneumoftiziology Institute \\ Corresponding author: \\ Mariana Anton, MD \\ "Carol Davila" University of Medicine and Pharmacy, Bucharest \\ Colțea Clinical Hospital, Internal Medicine Department \\ Ion C. Brătianu 1, 030171 , Bucharest, Romania \\ Tel +40213874300,0213874100 \\ Fax +40213874101
}

Email secretariat@coltea.ro

\section{Rezumat}

Introducere. Sarcoidoza este o boală sistemică, ce poate afecta orice organ, localizările pulmonară și la nivelul nodulilor limfatici intratoracici fiind cele mai frecvente. În ciuda încercărilor de a înțelege exact mecanismul patogenic al bolii, acesta nu este încă pe deplin elucidat. Din punct de vedere histopatologic, caracteristica principală a sarcoidozei este aspectul de granulomatoză non-necrotizantă.

Prezentarea cazului. Pacient în vârstă de 33 de ani, fără antecedente patologice semnificative, se prezintă în regim ambulator pentru adenopatii supraclaviculare și axilare bilaterale, astenie fizică progresivă în ultimele trei luni și durere latero-toracică apărută cu câteva zile anterior prezentării. Neagă febră, odinofagie sau scădere ponderală.

Clinic, pacientul este afebril, prezintă adenopatii supraclaviculare, laterocervicale și axilare bilateral, elastice, mobile, nedureroase, cu diametru maxim de $1.5 \mathrm{~cm}$, ficat cu diametru prehepatic de $16 \mathrm{~cm}$, cu margine rotunjită, splină nepalpabilă.

Analizele de laborator decelează sindrom inflamator moderat cu proteină $C$ reactivă (PCR) $1.4 \mathrm{mg} / \mathrm{dL}(\mathrm{N}<0,5 \mathrm{mg} / \mathrm{dL})$ și viteză de sedimentare a hematiilor (VSH) - $65 \mathrm{~mm} / \mathrm{h}(\mathrm{N}<40$ $\mathrm{mm} / \mathrm{h}$ ), fără limfocitoză/fără neutrofilie. Consultul ORL a fost în limite normale, nedecelând elemente de angină și excluzând, coroborat cu investigațiile biologice, mononucloza infecțioasă.

Diagnosticul prezumtiv este dificil din cauza simptomatologiei fruste și încadrează următoarele patologii: limfomul, mononucleoza infecțioasă, sarcoidoza, tuberculoza și vasculitele sistemice. 


\section{INTERNAL}

Clinical Cases.

Radiografia pulmonară decelează hiluri pulmonare cu arie de proiecție mărită, difuz conturate- aspect adenopatic/ tumoral, modificări interstițiale difuze și opacități micronodulare cu intensitate medie, difuz conturate, cu tendința la confluare bazal stânga și ușoară lărgire asimetrică a mediastinului superior, pe partea dreaptă paratraheal - aspect adenopatic.

Biopsia ganglionară obiectivează granulomatoză non-necrotizantă limfoganglionară, sugestivă pentru diagnosticul de sarcoidoză.

Se dozează angiotensin convertaza, relevând valori crescute ale acesteia de 108,20 U/L (N 13,3-63,9 U/L) și se recomandă consult pneumologic de specialitate.

Concluzie. Este vorba despre cazul unui pacient tânăr diagnosticat cu sarcoidoză. Diagnosticul a fost dificil, având în vedere simptomatologia nespecifică și multitudinea patologiilor care se pot încadra în categoria diagnosticelor diferențiale.

Cuvinte cheie: poliadenopatii, sarcoidoză, granulomatoză non-necrotizantă, angiotensin convertază.

\section{Abstract}

Introduction. Sarcoidosis is a multisystemic disease, that can basically affect any organ of the body, the lungs and the intrathoracic lymph nodes being the most affected. Despite the attempts to understand the exact pathogenic mechanism of the disease, this continues to remain uncertain. Histopathologically, the trademark of sarcoidosis is the presence of nonnecrotizing granuloma.

Case presentation. We report the case of a 33-year-old man without significant past medical history, who is admitted to our clinic for bilateral supraclavicular and axillary adenopathies, progressive asthenia for the last three months and pain in the latero-thoracic region. The patient denies weight loss, odynophagia and fever.

Clinically, the patient is afebrile and has supraclavicular, bilateral laterocervical and axillary adenopathies which are painless, elastic and mobile with a maximum diameter of $1.5 \mathrm{~cm}$. The prehepatic diameter is $16 \mathrm{~cm}$, with rounded inferior edge and the spleen in not palpable.

The laboratory tests reveal moderate inflammatory syndrome, with C-reactive protein (CRP) of $1.4 \mathrm{mg} / \mathrm{dL}(\mathrm{N}<0.5 \mathrm{mg} / \mathrm{dL})$ and the erythrocyte sedimentation rate (ESR) $65 \mathrm{~mm} / \mathrm{h}$ $(\mathrm{N}<40 \mathrm{~mm} / \mathrm{h})$. There is no lymphocytosis or neutrophilia. The ENT (Ear Nose Throat) consultation found no evidence of angina and, combined with the paraclinical investigations, excluded mononucleosis. 
Thus, the presumptive diagnosis was difficult because of the non-specific symptomatology and included the following: lymphoma, mononucleosis, sarcoidosis, tuberculosis and systemic vasculitis.

The chest X-ray reveals enlarged pulmonary hilums, diffuse outlined-adenopathic/ tumoral aspect, diffuse changes in the pulmonary interstitium and micronodular opacities of medium intensity, being diffusely outlined with the tendency of basal merging on the left side and slight asymmetrical enlargement of the superior mediastinum on the right side, para trachealadenopathic aspect.

The lymph node biopsy reveals the aspect of non-necrotizing granuloma, which suggests the diagnosis of sarcoidosis.

We used the dosage of angiotensin convertase, which reveals high values of $108.20 U / L$ ( $N$ 13.3-63.9 U/L). Therefore, a pulmonary clinical evaluation was recommended.

Conclusion. Case of 33-year-old man with sarcoidosis. The diagnosis was difficult, considering the non-specific symptomatology and the numerous pathologies that can be included in the differential diagnosis.

Keywords: poliadenopaties, sarcoidosis, non-necrotizing granuloma, angiotensin convertase.

\section{Introduction}

Sarcoidosis is a granulomatous disease of unknown etiology, which affects people all over the world $^{(2)}$. The histologic trademark of sarcoidosis is the non-necrotizing granuloma, which contains: macrophages, epithelioid cells, mononuclear cells, CD4+ and peripheral CD8+ lymphocytes ${ }^{2)}$.

The annual incidence of sarcoidosis among adults varies depending on the ethnicity. The maximum incidence is between AfroAmerican natives (17-35 per 100.000 population), followed by the white population (5-12 per 100.000 population). The lowest incidence is among Asiatic and Hispanic natives (1-3 per 100.000 population) ${ }^{\beta}$.

There is a slight predominance among women, which is more pronounced for the AfroAmerican population, where the female to male prevalence ratio is almost $2: 1$. Sarcoidosis generally affects people between 35 and 50 years old. The most affected organs are the lungs and the intrathoracic ganglions ${ }^{(4)}$. The most frequent symptoms are: coughing, dyspnea and chest tightness.

\section{Case report}

A 33-year-old patient, non-smoker, with no significant past medical history, was admitted in ambulatory regimen to our clinic in January 2020 for bilateral supraclavicular and axillary adenopathies, progressive asthenia and latero-thoracic pain. Complete anamnesis reveals familial history of pulmonary neoplasm (father) and also a previous presentation to our clinic, in 2017, for abdominal pain, alternating transit diarrhea-constipation, dry cough for a week, muscular pain and asthenia. In 2017, the chest $X$-ray is suggestive for a right sided hilar adenopathy (Figure 1-Chest X-Ray from 2017). A thoracic CT (Computer Tomography) scan was recommended, but the patient ignored the indication. 


\section{Clinical examination}

On the admission, the patient was afebrile, had bilateral supraclavicular, latero-cervical and axillary adenopathies which were elastic, mobile and painless with a maximum diameter of $1.5 \mathrm{~cm}$. The spleen was not palpable, the liver had a prehepatic diameter of $16 \mathrm{~cm}$ with a rounded inferior margin. Also, the ENT examination was normal, identifying no elements of angina.

\section{Investigations}

Usual laboratory tests, including complete blood count and biochemistry panel (creatinine, uric acid, transaminase, glycaemia) were within normal except for a moderate inflammatory syndrome with $\mathrm{C}$ reactive protein (CRP) of $1.4 \mathrm{mg} / \mathrm{dL}(\mathrm{N}<0.5$ $\mathrm{mg} / \mathrm{dL}$ ) and erythrocyte sedimentation rate (ESR) of $65 \mathrm{~mm} / \mathrm{h}(\mathrm{N}<40 \mathrm{~mm} / \mathrm{h})$.

The chest X-ray (Figure 2 - Chest X-ray) reveals the following abnormalities: bilateral hilar lymph node enlargement, diffuse outlined-adenopathic/ tumoral aspect, diffuse changes in the pulmonary interstitium and micronodular opacities of medium intensity, diffusely outlined with the tendency of basal merging on the left side and easy asymmetrical enlargement of the superior mediastinum on the right side, para tracheal-adenopathic aspect.

Cardiac ultrasonography reveals a single adenopathy $(3.5 \mathrm{~cm}$ in diameter $)$, which compresses the left atrium. Cervical ultrasonography describes right sided supraclavicular adenopathy with a maximum diameter of $1.6 \mathrm{~cm}$ and left sided supraclavicular adenopathy with a maximum diameter of $1.5 \mathrm{~cm}$.

Abdominal ultrasonography reveals no paraaortic adenopathies, and no hepatosplenomegaly. Computer tomography reveals multiple bilateral supraclavicular adenopathies, affecting all the mediastinal groups and some adenopathies of smaller size in the superior abdomen. Additionally, it shows extensive parenchymal abnormalities: pulmonary micronodules and infiltrates, possibly suggestive of lymphoma (Figures $3,4,5,6,7)$.

Taking into consideration the multiple adenopathies that were clinically and paraclinically objectified and the age of the patient, ailments which have in common symptoms and signs such as adenopathies and asthenia were included in the possible diagnostic algorithm. Among these we mention: lymphoma, tuberculosis, systemic vasculitis, sarcoidosis and mononucleosis, the last one mentioned being excluded by the lack of fever, leukocytosis and angina (Table 1).

Due to the presence of multiple adenopathies, a biopsy was performed. The histopathologic result indicates nonnecrotizing granulomatosis, suggestive for 


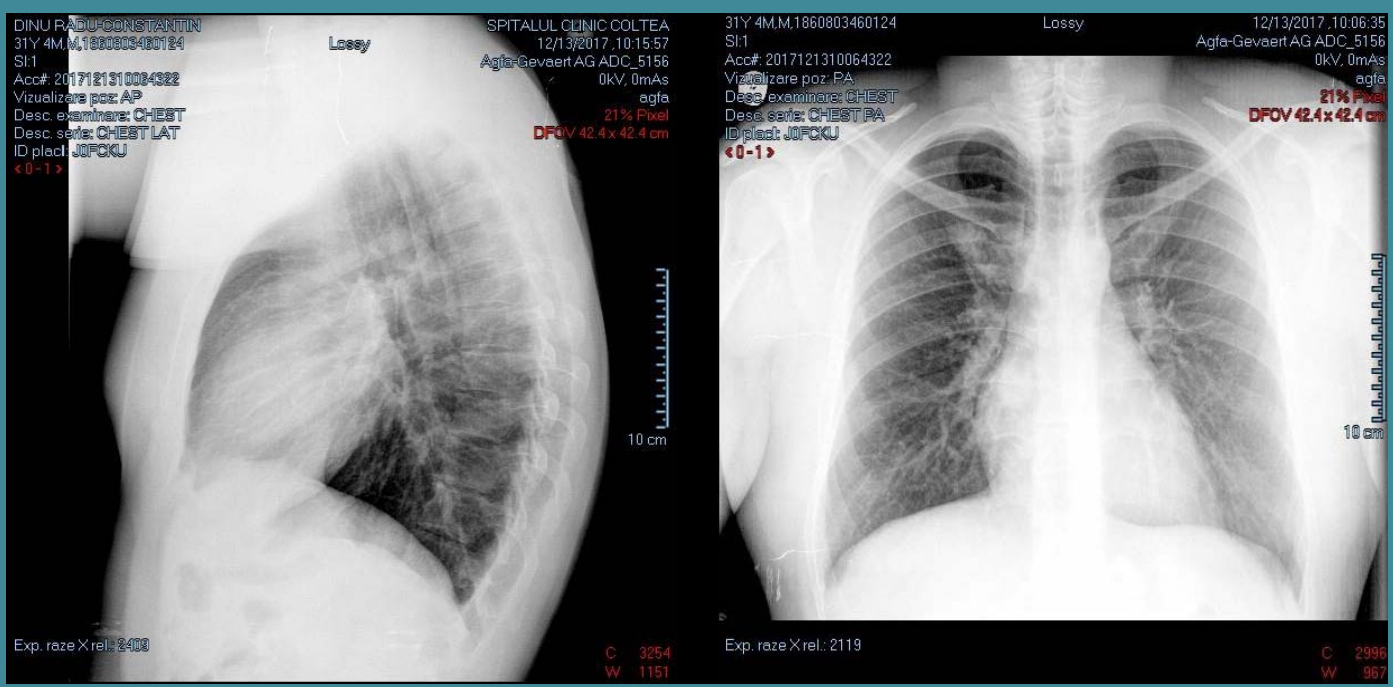

Figure 1. Chest X-ray from 2017 antero-posterior view (left) and profile (right), showing right sided adenopathy
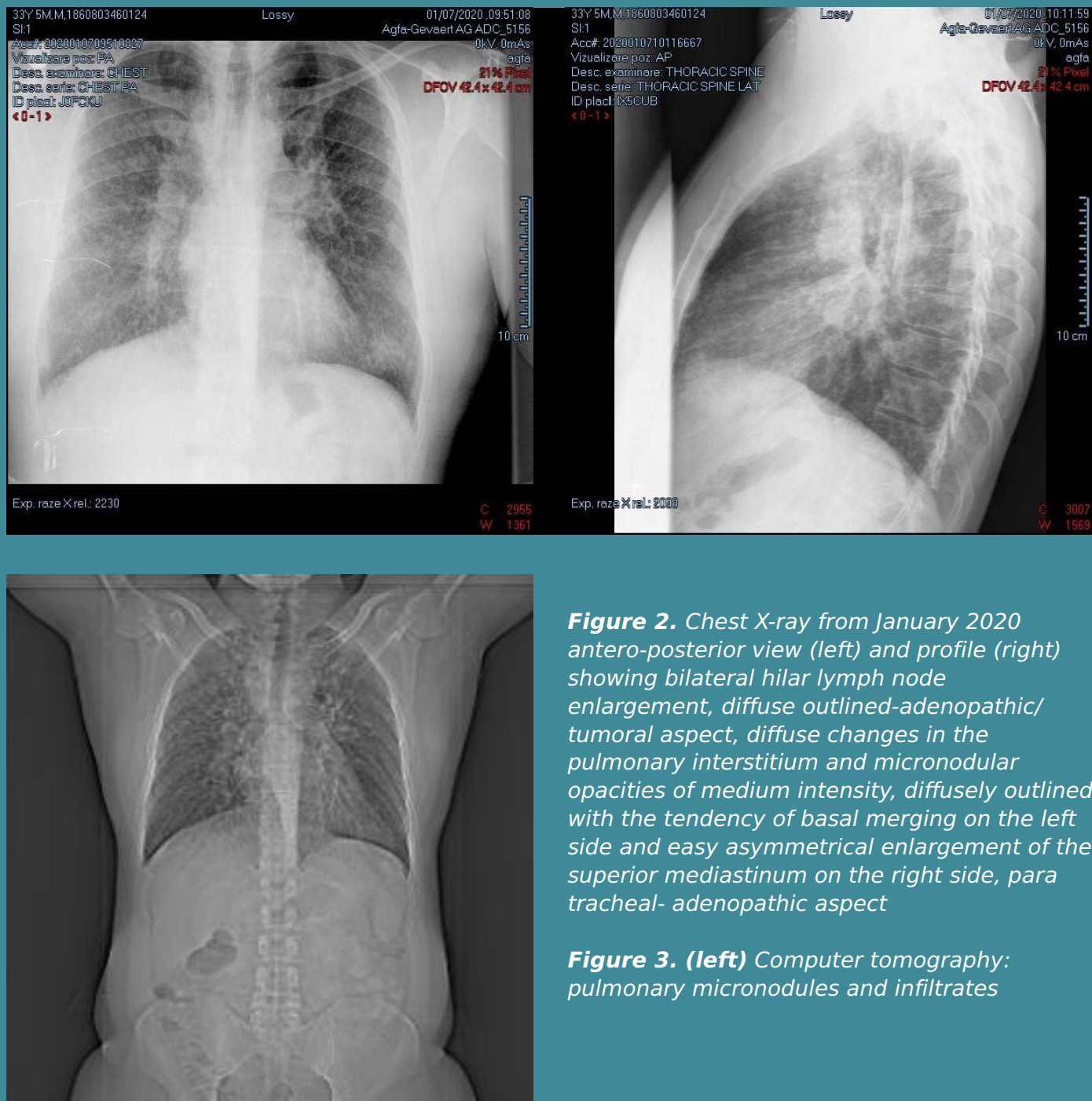

Figure 2. Chest X-ray from January 2020 antero-posterior view (left) and profile (right) showing bilateral hilar lymph node enlargement, diffuse outlined-adenopathic/ tumoral aspect, diffuse changes in the pulmonary interstitium and micronodular opacities of medium intensity, diffusely outlined with the tendency of basal merging on the left side and easy asymmetrical enlargement of the superior mediastinum on the right side, para tracheal- adenopathic aspect

Figure 3. (left) Computer tomography: pulmonary micronodules and infiltrates 


\section{INTERNAL MEDICINH}

\section{Clinical Cases.}

\begin{tabular}{|c|c|c|c|c|}
\hline \multicolumn{6}{|c|}{ Differential diagnosis } \\
\hline Lymphoma & Tuberculosis & Systemic vasculitis & Sarcoidosis & $\begin{array}{c}\text { Infectious } \\
\text { mononucleosis }\end{array}$ \\
\hline Adenopathies & Adenopathies & Adenopathies & Adenopathies & Adenopathies \\
\hline Fever & Fever & Fever & Fever & Fever \\
\hline Weight loss & Weight loss & Weight loss & Weight loss & Asthenia \\
\hline Asthenia & Asthenia & Asthenia & Asthenia & Nocturnal sweats \\
\hline Nocturnal sweats & Nocturnal sweats & Nocturnal sweats & Cough & Pharyngitis \\
\hline & Cough & & Thoracic pain & \\
\hline
\end{tabular}

Table 1. Differential diagnosis (the patient's symptoms are highlighted)

\section{Features and Frequency of Pulmonary Sarcoidosis Stages}

\begin{tabular}{|c|c|c|}
\hline Stage & \multicolumn{1}{|c|}{ Radiographic features } & $\begin{array}{c}\text { Frequency at presentation } \\
(\%)\end{array}$ \\
\hline I 10,13
\end{tabular}

Table 2. Radiographic staging of sarcoidosis ${ }^{(3)}$ 


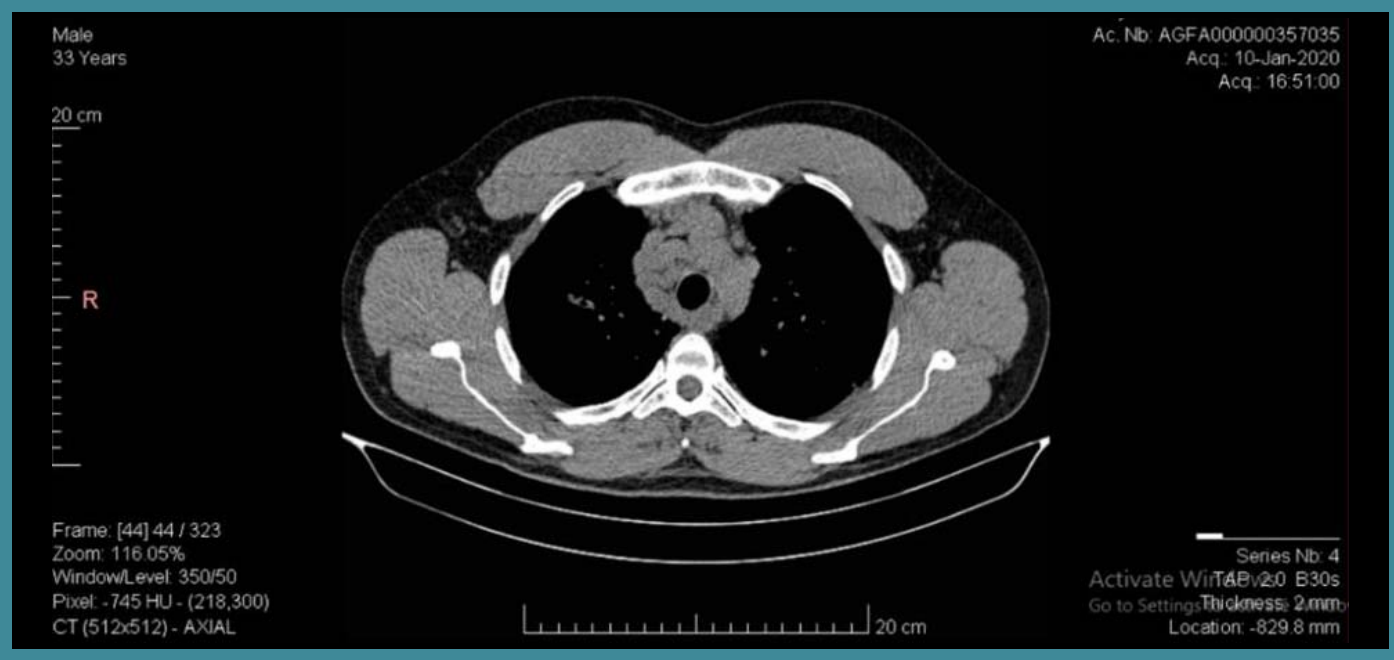

Figure 4. Computer tomography: mediastinal adenopathy mass

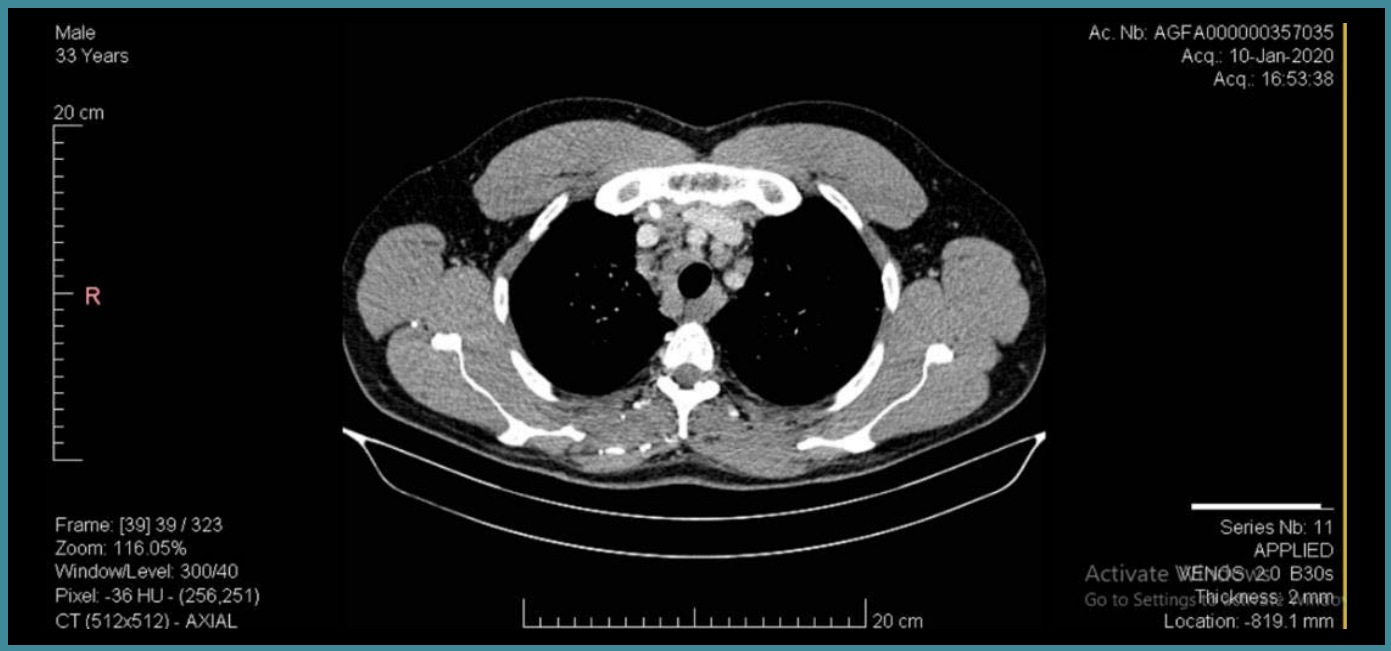

Figure 5. Computer tomography: mediastinal adenopathy mass

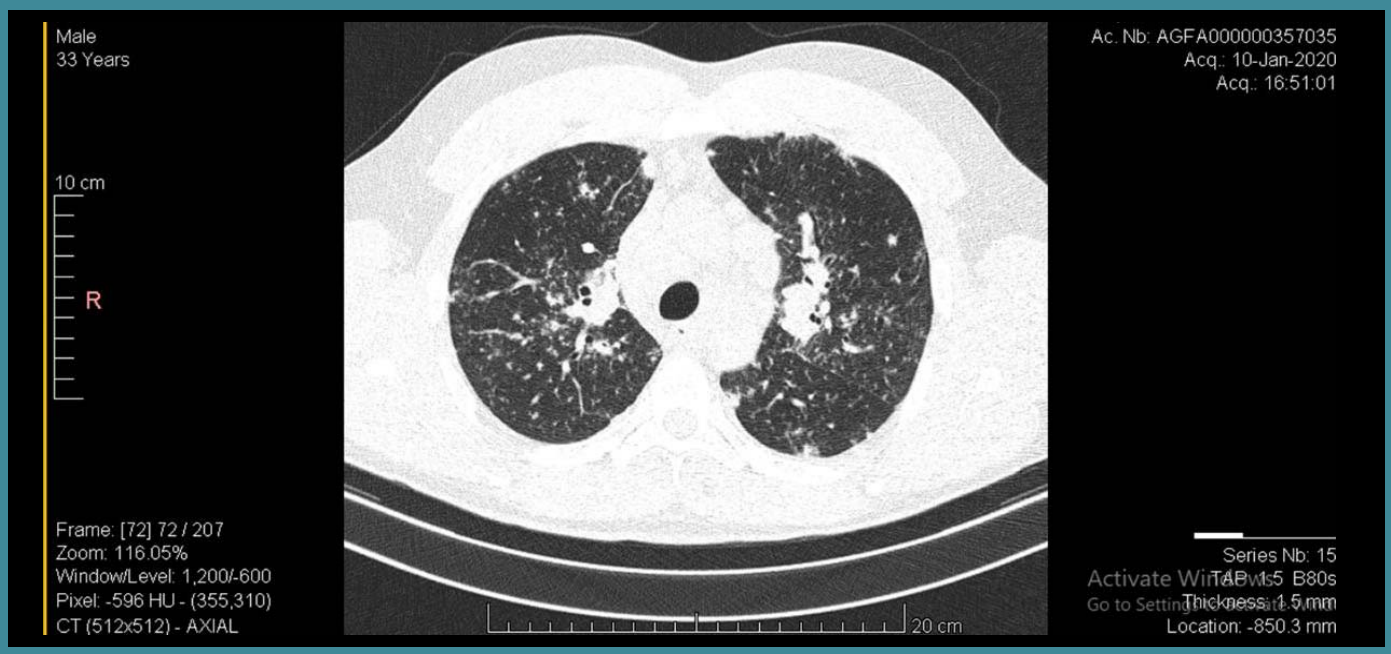

Figure 6. Computer tomography: pulmonary micronodules and infiltrates 


\section{Clinical Cases.}

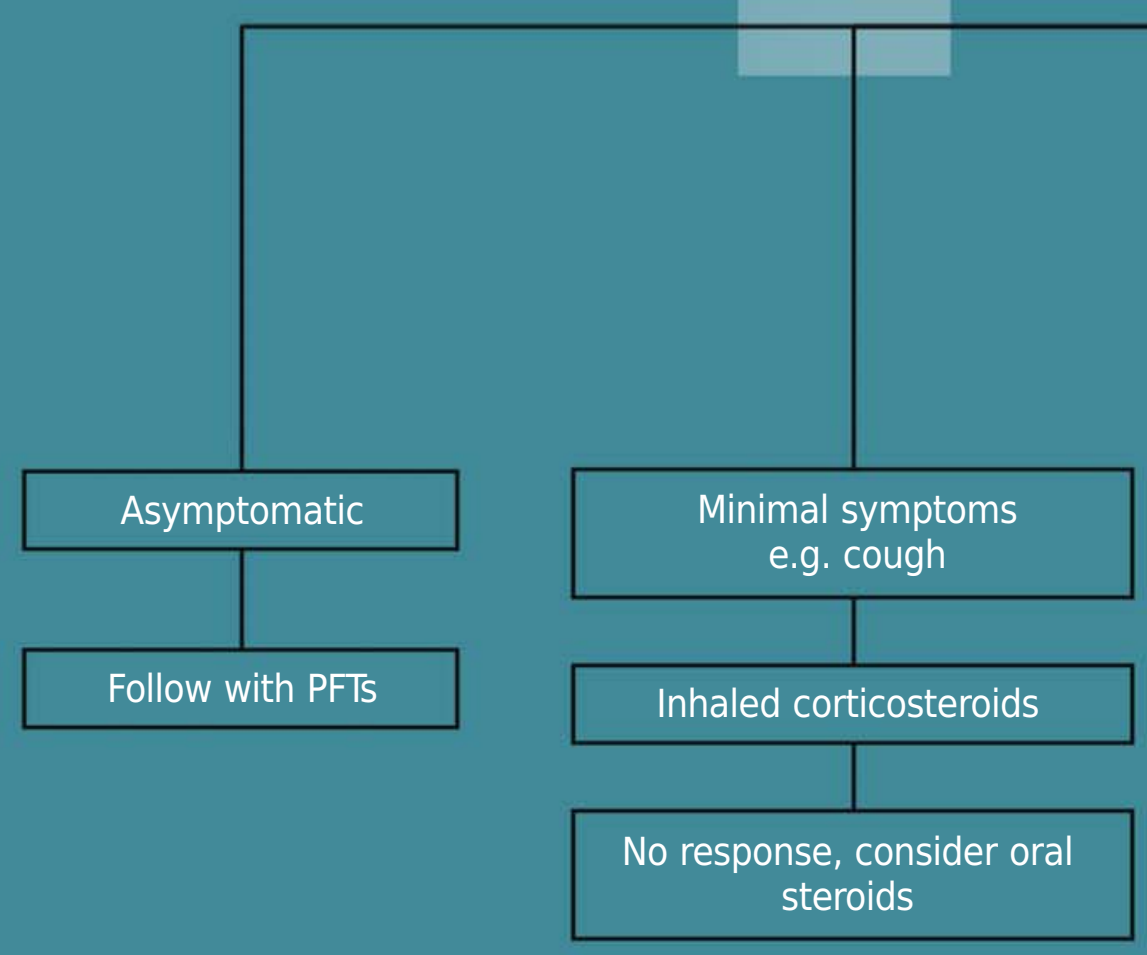

*Where prednisone is indicated, an equivalent dose of corticosteroids (i.e. methylprednisolone) could also be used.

+Cytotoxic drugs include: methotrexate, azathioprine, mycophenolate and leflunomide.

++ Anti-TNF therapy includes infliximab and adalimumab.

+++ If unresponsive or intolerant of anfi-TNF agent, Acthar gel or rituximab may be considered.

Figure 8. Pulmonary sarcoidosis treatment guide ${ }^{(5)}$ 


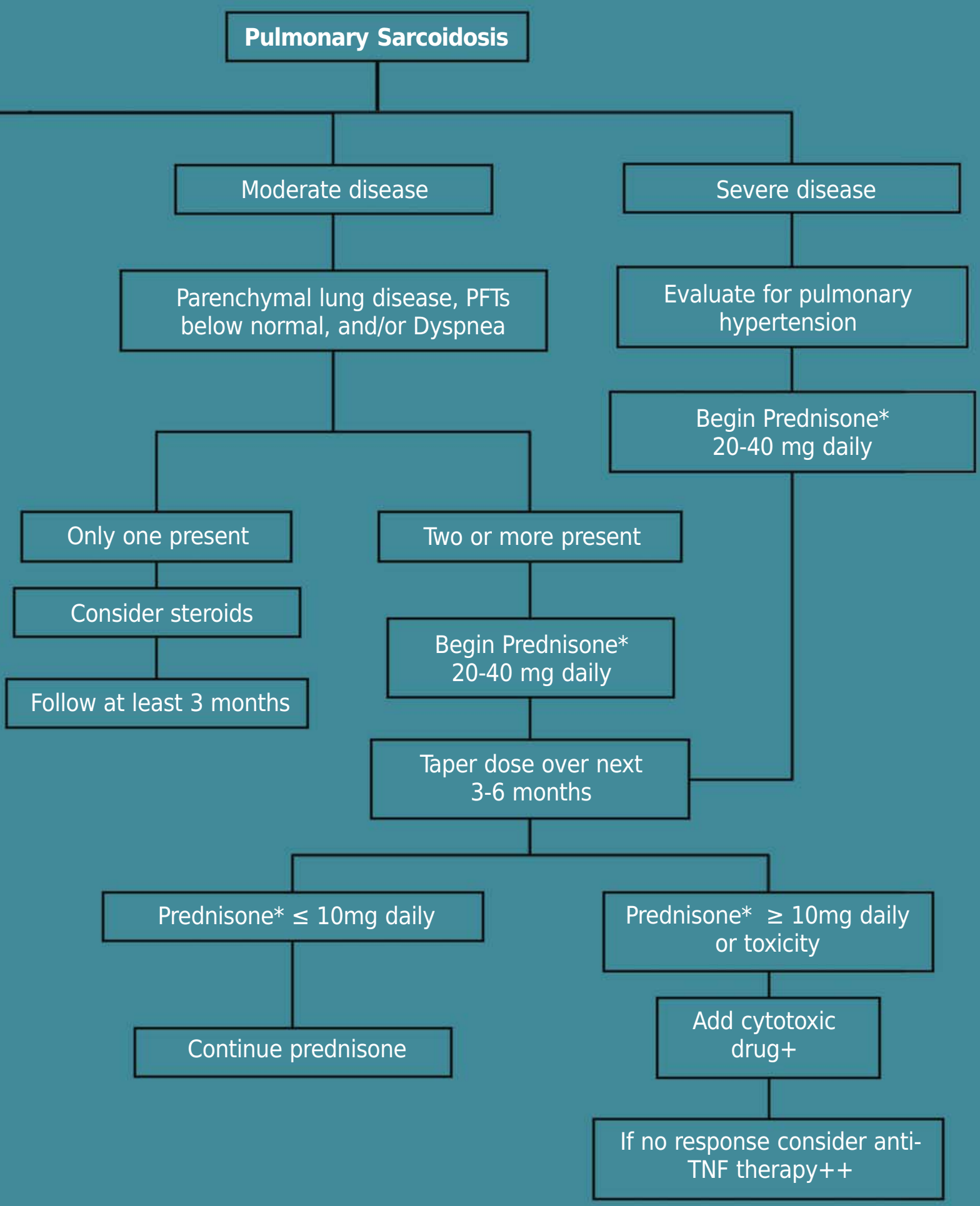




\section{INTERNAL MEDI}

Clinical Cases.

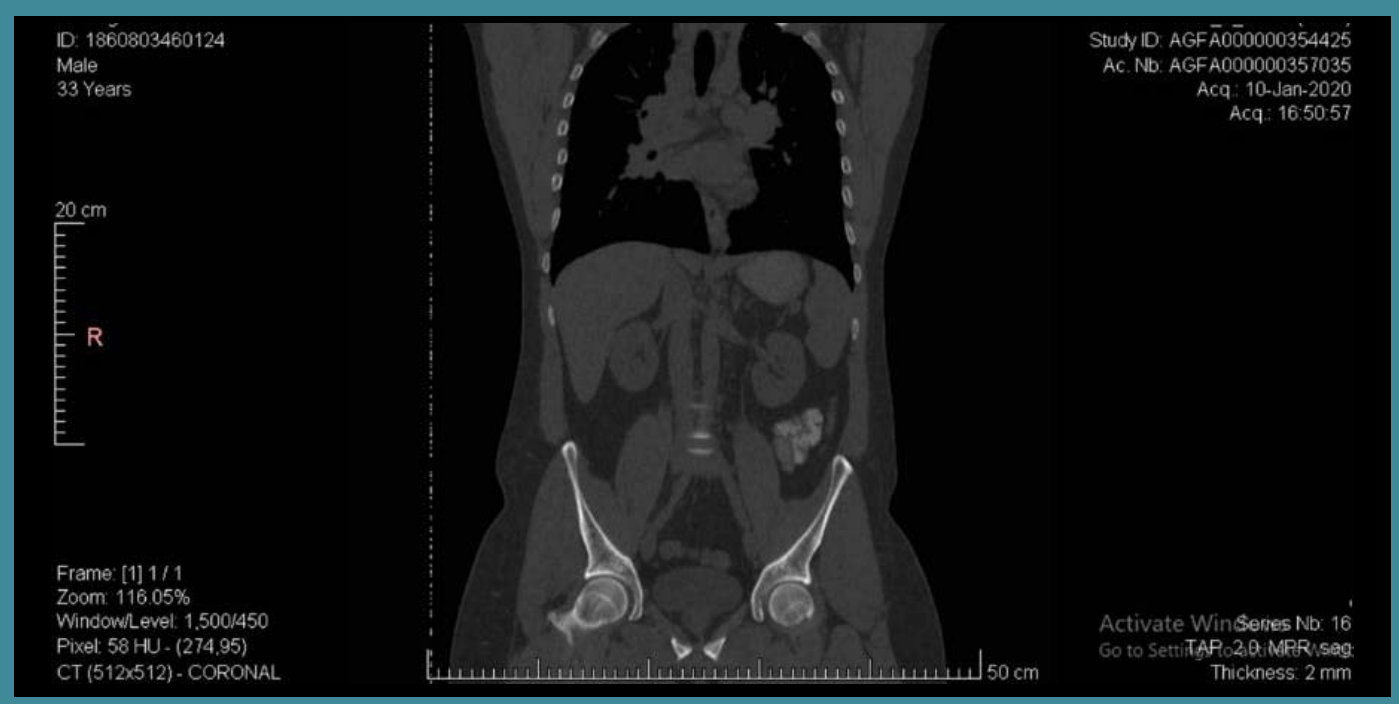

Figure 7. Computer tomography: adenopathies compressing the left atrium

sarcoidosis. Taking into consideration this result, dosage of angiotensin convertase and a pulmonary clinical evaluation were recommended.

Angiotensin convertase had high values of 108.20U/L (N: 13.3-63.9U/L).

The pulmonary evaluation reveals normal values of the respiratory flows, the vital capacity and the total pulmonary capacity at the lower limit of the normal, slightly lowered alveolar-capillary diffusion with normal transfer factor of the lung, modifications that are specific for the restrictive syndrome, which is also suggestive for the diagnosis of sarcoidosis. Considering the symptomatology, biological and paraclinical investigations, the patient was diagnosed with sarcoidosis. The disease was classified based on the pulmonary radiography as stage III. (Table 2-Radiographic staging of sarcoidosis).

Due to the symptomatology of the patient, the stage of the disease and the functional respiratory tests that were on the lower limit of the normal, corticosteroid treatment is initiated according to the current guides. (Figure 8-Pulmonary sarcoidosis treatment guide). The treatment is usually initiated with 20-40mg/day prednisone or equivalent. In 
this case we started treating with $32 \mathrm{mg} /$ day methylprednisolone, the equivalent of $40 \mathrm{mg}$ prednisone for one month.

\section{Discussions}

We have presented the case of a 33-year-old male patient diagnosed with stage III sarcoidosis.

The frequency at presentation of this stage is $15-20 \%$ as described in Table $2^{(\beta)}$. The most common symptoms of sarcoidosis are: dry cough ( $30 \%$ cases), extrathoracic localizations- mainly peripheral lymph nodes, constitutional symptoms such as fatigue ( $27 \%$ )-(all of the above being present in this case) and weight loss (28\%), fever (10$17 \%)$ or night sweats and erythema nodosum $(3-44 \%)^{(6,7)}$.

The particularity of this case consisted in the non-specific symptomatology (asthenia, adenopathies) that was hardly differentiated from other pathologies such as: lymphoma, tuberculosis, mononucleosis and systemic vasculitis. Another particularity was the dragging evolution of the disease that made the diagnosis even harder.

The prognosis of sarcoidosis depends on the stage at presentation, complications, level of pulmonary fibrosis and how it debuts. Taking this factors into consideration the following statements can be made:

- $20-25 \%$ of the patients develop respiratory insufficiency because of the fibrosis that leads to losing the alveolar diffusion capacity;

- $5-10 \%$ of the patients die because of the complications;

- Progressive onset of the disease has a poorer outcome than the acute one (erythema nodosum) because it can be followed by fibrosis 8 .

- Only one third of the patients that presents with stage III sarcoidosis improve within two years or show eventual clearing of the chest radiography 9 .

- Positive prognostic factors are the patient's age (33 years old) and the non-smoking status.

Most of the patients diagnosed with sarcoidosis do not require any specific treatment, but when this is required, glucocorticoids are the first line regimen. A study from the Mayo Clinic in Rochester, Minnesota, found that oral glucocorticoids were required in only about one-third of the patients with pulmonary sarcoidosis ${ }^{(10)}$. The ATS/ERS/WASOG statement suggests systemic therapy only for patients with progressive symptomatic disease, persistent pulmonary infiltration, and progressive decline of lung function ${ }^{(11)}$.

In this case the treatment was initiated because of the persistent symptomatology of the patient, because of the impaired pulmonary functioning tests (PFTs) and the advanced stage found on the chest X-ray evaluation. The treatment consisted of $32 \mathrm{mg}$ of methylprednisolone a day for 30 days which is the equivalent for $40 \mathrm{mg}$ of prednisone. After one month the dose is lowered by $16 \mathrm{mg}$ per day and should be continued until further evaluation, which can decide further dosage change.

In conclusion we have presented the case of a 33-year-old patient diagnosed with stage III sarcoidosis, with poor prognosis because of the impaired PFTs and progressive onset.

Data published with the informed consent of the patient.

\section{References}

1. Baughman RP, Culver DA, Judson MA, Carolina $S$. Concise Clinical Review A Concise Review of Pulmonary Sarcoidosis. 2(11). doi:10.1164/rccm.201006-0865Cl 
2. Thomas KW, Hunninghake GW. Sarcoidosis. 2015;289(24).

3. Ms PU, Ryu JH, Mph ELM. Clinical Manifestations, Diagnosis, and Treatment of Sarcoidosis. Mayo Clin Proc Innov Qual Outcomes. 2019;3(3):358-375. doi:10.1016/j.mayocpiqo.2019.04.006

4. Baughman RP, Field S, Costabel U, et al. Sarcoidosis in America Analysis Based on Health Care Use. 2016;13(8). doi:10.1513/AnnalsATS.201511-7600C

5. Treatment P. SARCOIDOSIS TREATMENT GUIDELINES.

6. Nunes $H$, Bouvry $D$, Soler $P$, Valeyre $D$. Orphanet Journal of Rare. 2007;8:1-8. doi:10.1186/1750-1172-2-46
7. The TOF, Adopted WAS, The BY, Of $O$, The BY. Statement on Sarcoidosis. 1999;(3).

8. lerce TADABUP, Argolis MAM, Azzuk MAAR. Sarcoidosis: still a mystery? 2001;75205:8-12.

9. Higgs R. Prognosis in sarcoidosis. 1984;288(May):1557-1558.

10. Ungprasert $P$, Clinic C, Crowson CS, Matteson E. Outcome of pulmonary sarcoidosis?: A population-based study 1976-2013 Outcome of pulmonary sarcoidosis?: a population-based study. 2018;(August 2019).

11. Costabel U, Hunninghake GW, Statement $S$. EDITORIAL ATS / ERS / WASOG statement on sarcoidosis. 1999:735-737. 